ISSN: $2318-1966$

v. 3, n. 3

NOVOS RUMOS SOCIOLÓGICOS

jan - jun 2015

Dossiê

\title{
O DESEJO PELA BRANQUITUDE E O FANTASMA DAS DIFERENÇAS RACIAIS: NEGOCIAÇÕES DAS DIFERENÇAS A PARTIR DO USO DOS BATE-PAPOS NA CIDADE DE SÃO CARLOS
}

\author{
Keith Diego Kurashige \\ Doutorado do Programa de Pós Graduação \\ em Sociologia da Universidade Federal de São Carlos
}

\begin{abstract}
RESUMO
Este artigo apresenta alguns resultados da minha pesquisa de mestrado, que envolveu usuários de um site de relacionamento em uma cidade média do interior paulista. Desenvolvido em 2012 a 2014, a investigação procurou compreender como homens, que buscam se relacionar homoeroticamente em segredo, negociam as suas diferenças sociais, em especial a "raça" , nos bate-papos voltados para o público da cidade de São Carlos-SP. Foram feitas observações da plataforma e também interações (que articularam as esferas interdependentes on /off-line) com os usuários, a fim de entender como estes fazem o uso das mídias digitais e negociam os seus desejos. Embora seja datada, esta pesquisa apresenta dados importantes que contribuem para entender como está se dando o uso dos bate-papos em um contexto localizado e também mostra como a gramática erótica deve ser compreendida em sua heterogeneidade e de modo contextual. Levando em consideração as especificidades do contexto são-carlense, o artigo mostra que os usuários do bate-papo refletem ideais de branquitude e os fantasmas das diferenças racializadas constituídas historicamente que fundamentam as suas buscas desejantes.
\end{abstract}

Palavras-chave: Mídias Digitais; Diferenças; Negociações.

\section{THE DESIRE FOR WHITENESS AND THE GHOST OF RACIAL DIFERENCES: NEGOTIATIONS OF DIFFERENCES FROM THE USE OF CHATS IN THE CITY OF SÃO CARLOS}

\begin{abstract}
This article presents some results from my Master' $\mathrm{s}$ degree research, which involved users from a social networking site in a medium-sized town in the countryside of São Paulo. Developed between 2012 and 2014, the investigation tried to comprehend how men who are looking for a secret homoerotic-relationship negotiates their social differences, specially "race" , in chats focused on the community of the city of São Carlos-SP. Observations were made of the platform and the interactions (which articulated the interdependent spheres online and off-line) with the users, in order to understand how they use digital medias and negotiate their desires. Although dated, this research presents important data that contributes to understand how chats are being used in a specific context and also shows how erotic grammar should be understood in its heterogeneity and in a contextual way. Taking into consideration the specificities of the são-carlense context, the article shows that chat users reflect ideals of whiteness and the ghosts of racialized differences historically constituted that grounds their desiring search.
\end{abstract}

Key-words: Digital Media; Differences; Negotiations. 
NORUS - v3, n.3, jan - jun 2015.

\section{Introdução}

Os meios de comunicação se desenvolveram ao longo dos tempos, possibilitando diversas formas de interação entre as pessoas. A rede interligada de computadores, mais conhecida como internet, foi um dos adventos mais relevantes de nossa sociedade contemporânea, a qual segundo Richard Miskolci (2013, p.43) teve seu uso comercial expandido no Brasil a partir de 1997, sendo assim um fenômeno recente.

Segundo o sociólogo (p.43), os computadores pessoais entraram em cena na década de 1980, e somados às novas invenções tecnológicas possibilitaram que eles fossem conectados por meio de telefones pessoais, que permitiram o uso comercial da internet na década de 1990 . No Brasil isto ocorreu um pouco mais tarde, pois, ao contrário dos países considerados “centrais", onde os telefones residenciais se tornaram comuns a partir da década de 1950, no território brasileiro os telefones residenciais mantiveram-se caros, e eram encontrados apenas nas casas das classes mais altas até os anos de 1980. A privatização dos meios de comunicação na década de 1990 proporcionou um expressivo aumento de acesso à linhas telefônicas, aumentando os serviços de internet comercial que foram se acentuando a partir de 1997.

O autor afirma que o ano de 1997 também é um ano crucial para a compreensão deste novo cenário no contexto das homossexualidades brasileiras, pois é um ano marcado por vários eventos significativos, como o surgimento comercial da internet, a distribuição gratuita de medicamentos para o tratamento do HIV, e também por se tratar do ano em que a Parada do Orgulho Gay de São Paulo ganhou um destaque mundial. Estes fatos são associados à uma virada histórica na forma como a sociedade brasileira compreende o universo das homossexualidades. A internet tornou possível a criação de redes relacionais de pessoas que viviam seus desejos predominantemente em segredo, e, além disso, o tratamento com medicamentos de AIDS começou, pouco a pouco, a diminuir o pânico sexual que tinha surgido em torno da epidemia, o que trouxe uma nova forma de ver a doença, não mais como fatal, mas como crônica e que podia ser tratada. O ano de 1997 foi, portanto, o ano em que as pessoas passaram a experimentar “ formas mais positivas da visibilidade política e da mídia” (MISKOLCI, 2013, p. 44).

Para se pensar a sexualidade é necessário levar em consideração as formas específicas de sua construção, o que, no presente, envolve atentar para a forma como ela se articula com a disseminação das mídias digitais. O uso das mídias digitais transformou o modo de se 


\section{O desejo pela branquitude e o fantasma das diferenças raciais: negociações das diferenças a partir do uso dos bate-papos na cidade de São Carlos}

relacionar entre as pessoas. $\mathrm{Na}$ esfera das homossexualidades, ela incorporou e disseminou um fenômeno que funcionava por outras mídias a exemplo dos “anúncios publicados em jornais há pelo menos 30 anos [os quais] evidenciam que a busca de parceiros/as não se dá somente nas interações face-a-face” (BELELI, 2012, p.1-2).

As mídias digitais se relacionam com o desejo de vivenciar relações homoeróticas em segredo, o que nos demanda fazer uma reflexão sobre o "armário" como um regime de visibilidade. A expressão “estar no armário” designa as pessoas que não revelaram sua orientação sexual em um ambiente presumidamente heterossexual, no qual a homossexualidade não é aceita ou pode vir a sofrer sanções. Já “sair do armário” designa o ato de revelar/expor a sua orientação sexual no espaço público, entre amigos e/ou na família. Obviamente, a despeito do “dentro/fora” auxiliar na descrição, o armário é um regime de visibilidade que opera por meio de um difícil exercício de manutenção de uma imagem pública segura, hétero, relegando relações homo ao segredo e à vida privada.

A teórica queer Eve Kosofsky Sedgwick (2007), em sua análise sobre o “armário” , reflete sobre como esse dispositivo regula as sexualidades hétero e homo desde o final do século XIX. O “armário” , segundo a autora, é um regime regulador da separação binária entre heterossexualidade e homossexualidade, sendo a primeira a esperada e aceita na esfera pública, e a segunda restrita e incentivada apenas em segredo e, portanto, relegada à esfera privada. Não podemos reduzir o “armário” como algo concernente apenas às pessoas que se relacionam com outras do mesmo sexo, relegando sua vida amorosa/sexual ao segredo e à esfera privada, pois o armário diz respeito também às pessoas que podem viver outras práticas sexuais abertamente. Em outras palavras, o armário regula o que a sociedade considera respeitável e lícito, garantindo-lhe visibilidade, enquanto rejeita as relações “ilícitas” ou não respeitadas a vivência em segredo, o que, no caso das relações entre pessoas do mesmo sexo, equivale a vivê-las no “armário” . O privado e o público estão sempre relacionados e o armário é um de seus eixos na esfera amorosa e afetiva contemporânea.

Além disso, Sedgwick constata que o armário é um “espaço epistemológico pesado, ocupado e consequente" (SEDGWICK, 2007, p.35), não se podendo estar dentro ou fora dele somente por decisão individual. Segundo a autora, o armário não pode ser visto como somente repressor, pois ele opera em termos de disciplina e controle.

Refletindo sobre as teorias de Sedgwick, Miskolci (2007) afirma que a autora atentava sobre a necessidade de adaptar a sua metodologia de análise a outros contextos sociais e 
históricos. Para Miskolci, não podemos pensar o armário nos termos “norte-americanos” se formos fazer uma análise no Brasil, ou seja, devemos partir da ideia de que cada sociedade tem suas peculiaridades e formas diversas de se compreender a sexualidade, os gêneros e o erotismo. Em sua reflexão sobre o contexto brasileiro, o autor aponta que a "vida dupla" segue uma lógica própria desde os tempos de colonização. Partindo dessa concepção, o sociólogo elucida que "essa forma de regular a sexualidade (assim como as relações interraciais) marca a vida de todos, mas têm consequências incomparáveis para pessoas homoorientadas ” (MISKOLCI, 2007, p. 60). Nesse contexto é compreensível que as mídias digitais estão sendo usadas como uma "válvula de escape", onde os desejos podem ser experienciados em segredo, o que possibilita driblar as restrições morais e coletivas.

Em um outro artigo, Miskolci (2014) afirma, em sua leitura sobre Sedgwick, que “ visibilidade ou invisibilidade estão intrinsecamente associadas à regimes de verdade, a códigos morais, a valores que fogem ao controle dos indivíduos” (p.17). Neste sentido, o autor considera que

o duo armário-assumir-se é não apenas algo cuja dinâmica é circunscrita predominantemente à experiência norte-americana das classes superiores brancas, mas, principalmente, é apenas uma das formas de articulação entre visibilidade e regime de verdade, entre o que uma sociedade reconhece como existente dentro de um enquadramento moral. Há outras formas diferentes, inclusive nos Estados Unidos, de vivenciar e negociar a experiência de se engajar em relações amorosas e/ou sexuais com pessoas do mesmo sexo com as demandas familiares e sociais de heterossexualidade. (MISKOLCI, 2014, p.18).

O sociólogo sugere voltarmos o " nosso olhar também para as pessoas que vivem suas relações em segredo buscando compreender que suas estratégias e táticas respondem a constrangimentos sociais que precisamos identificar e analisar” (p.18). Segundo o autor, no contexto brasileiro, a manutenção do espaço público, da família e da heterossexualidade é valorizada. Neste sentido, a associação do segredo sobre a homossexualidade com um universo moral é muito diferente de outros contextos como o norte-americano, que valoriza a vivência da sexualidade no espaço público (cf. p.5). Miskolci aponta que as dicotomias internas da sexualidade no Brasil são muito particulares, pois as diferenciações econômicas, sexuais e raciais se articulam, produzindo novas formas de viver e compreender a sexualidade. Partindo disso, este artigo tem como objetivo mostrar preliminarmente como estão se dando as interações articuladas/interseccionalizadas em sites de “bate-papo" voltados para o público de São Carlos. Nas salas de bate-papo, por suas próprias características de interação 


\section{O desejo pela branquitude e o fantasma das diferenças raciais: negociações das diferenças a partir do uso dos bate-papos na cidade de São Carlos}

instantânea e dialógica, características corporais e subjetivas são negociadas na busca pela constituição de relações amorosas e sexuais. Reconstituir e compreender como estas características são apresentadas, procuradas, e até mesmo recusadas, auxiliará a compreender como a gramática (homo)erótica se delineia a partir de valores e convenções culturais próprias à realidade brasileira contemporânea, os quais ainda esperam por ser melhor explicitados e compreendidos.

Minhas observações feitas entre os anos de 2012 a 2014 a partir dos chats (batepapos) da cidade de São Carlos, interior de São Paulo, mostram que as interações homoeróticas masculinas se dão prioritariamente em segredo. Umas das mais pertinentes e criteriosas perguntas, como “Você é afeminado? Do meio gay? Assumido?” , ou afirmações

“Não curto afeminados e não faço parte do meio gay" demonstram que a masculinidade e o sigilo são altamente valorizados nesta cidade de pouco mais de 220 mil habitantes. Um homem que diz não ser do meio, que não é assumido, é valorizado, pois esta condição aparentemente faz com que a pessoa guarde a interação, ou até mesmo um relacionamento, em segredo.

Em uma reflexão mais precisa sobre os segredos e mentiras nas interações homoeróticas, o sociólogo Richard Miskolci (2012a) constata que no contexto paulistano

\footnotetext{
é visível a predominância dos que se apresentam nas diversas plataformas com a demanda de constituir relações em segredo ou que, ao menos, declaram-se “ discretos” e/ou demandam parceiros sem sinais que os identifiquem como gays. [...] o sigilo aparece como o principal atrativo dessas mídias [...], eles permitem que neles expressem seus anseios, sintam-se desejados, partilhem experiências de forma a travar relações homossexuais que, esperam, os mantenham a salvo das amplamente conhecidas consequências negativas no espaço público e na vida cotidiana. (MISKOLCI, 2012a, p.16-17).
}

As relações homoeróticas são criadas e mantidas predominantemente em segredo, no entanto, não podemos pensar o “armário" como algo universal. Antes, devemos pensar o regime de visibilidade como contextual e levar em consideração que os sujeitos têm agência e vivem em uma constante negociação sobre o que querem mostrar ou esconder. As dinâmicas de como as relações homoeróticas são experienciadas diferem de acordo com o contexto onde estão inseridas. Diferente dos grandes centros metropolitanos, onde há um grande número de pessoas e espaços de sociabilidade homoerótica, São Carlos, uma cidade média do interior paulista, oferece menos opções, tanto de parceiros amorosos quanto de locais para interação social. 
NORUS - v3, n.3, jan - jun 2015.

Embora pareça que as mídias digitais democratizaram os relacionamentos amorosos/sexuais e que as racialidades estariam sendo apagadas nessas relações, o que meu campo investigado em São Carlos durante a pesquisa de mestrado mostra é que, muito pelo contrário, o que se passa é diferente, talvez mesmo o oposto. As mídias digitais radicalizaram os critérios de seleção pautados nas diferenças sociais, pois, diferente do que acontece off-line, o conhecimento que se tem sobre uma pessoa, precede a atração (cf. ILLOUZ, 2011, p. 113), e os atributos corporais são antes imaginados com base nos estereótipos e fantasias, já que a corporalidade encontra-se desfragmentada e facilmente é descontextualizada do todo subjetivo e corporal. Não nego que as mídias digitais proporcionaram a criação de plataformas pelas quais o racismo vem sendo contestado. As plataformas que analiso, contudo, são as de relacionamento, em especial os bate-papos, que vem sendo usados especialmente para a busca de parceiros em relações homoeróticas no contexto são-carlense.

A escolha pelo eixo racial para compreender como a racialidade é articulada nas buscas desejantes não foi aleatória. O interesse surgiu pelas minhas próprias experiências de sexo-racialização, o que me instigou a compreender como esses eixos de desigualdade social são articulados e negociados. É compreensível que, por consequência de uma recente tradição dos estudos sobre o uso das mídias digitais para os relacionamentos, as análises dessas relações estejam concentradas exclusivamente em torno da sexualidade e gênero, mas têm apontado para algumas articulações como a de classe, regionalidade, etc. Tenho a proposta de aprofundar desta forma, não ignorando as articulações, a reflexão sobre como a racialidade forjada historicamente - , é experienciada nos relacionamentos homoeróticos por meio das mídias digitais em uma cidade média do interior de São Paulo, São Carlos.

\section{O contexto e a lógica do uso dos bate-papos}

Diferentemente das salas disponibilizadas para o público das cidades metropolitanas, as quais algumas estão destinadas a pessoas que querem se relacionar homoeroticamente, para a cidade de São Carlos, uma cidade de médio porte do interior paulista, estão disponíveis apenas quatro salas com capacidade máxima de 30 participantes que, em tese, seriam para quaisquer relações, mas em que predominam homens em busca de outros homens. Tenho como hipótese que essa predominância visível da busca de relações entre pessoas do mesmo sexo nas salas se relaciona diretamente com a falta de espaços off-line e/ou condições segurança- para a paquera homossexual em São Carlos. 


\section{O desejo pela branquitude e o fantasma das diferenças raciais: negociações das diferenças a}

partir do uso dos bate-papos na cidade de São Carlos

A cidade tem apenas um bar, considerado pelas pessoas que frequentam como " do babado" , ou seja, um espaço frequentado por homossexuais. Teve também uma boate voltada para o público homoerótico masculino, inaugurada em maio de 2013, mas que fechou em novembro do mesmo ano por falta de público, e que era frequentada como uma falta de opção, quando não teriam condições para ir à outras festas em outras cidades. Por ser uma cidade localizada geograficamente perto de outras cidades médias, é comum ver aqueles que tem mobilidade se organizarem para ir às festas de cidades vizinhas, em especial Araraquara e Ribeirão Preto. Alguns sujeitos frequentam uma rua de São Carlos conhecida como " rua larga” para se relacionarem, mas é majoritariamente voltada para a prostituição.

A existência de poucos espaços comerciais de sociabilização homoerótica em São Carlos não significa que, por consequência, estes poucos locais são altamente frequentados. Pelo contrário, muitos se afastam deles para se distanciar de identificações homoeróticas, evitando se relacionar em público com outras pessoas do mesmo sexo. É como se a discrição sobre a homossexualidade lhes conferisse uma masculinidade insuspeita que não colocaria em risco sua aceitação em seus círculos sociais como família, trabalho e escola.

A escassez de pessoas que frequentam os meios de sociabilidades homoeróticas em São Carlos se dá também por causa da discriminação subjetiva, consequência da homogeneização forçada das diferenças de classe, raça e masculinidades. A falta de espaços de sociabilidade não distribui as pessoas em locais de acordo com os gostos sociais ou distinções de classe que parecem operar de forma mais forte na segmentação comercial heterossexual. Antes, ela força interações entre homens que não necessariamente partilham dos mesmos gostos musicais, interesses e atividades. Em suma, no incipiente meio homossexual local, homens de classe alta e média são levados a interagir com outros de classes populares, o que é motivo de comentários e reclamações constantes entre meus colaboradores.

Posso afirmar que o mesmo acontece nos bate-papos, onde é comum reclamações de que não há, segundo os usuários, “gente que preste” . Não se trata de pensar que nos chats as pessoas buscam se relacionar sem critérios, mas elas são modeladas segundo a expectativa de encontrar alguém que esteja em conformidade ao que é socialmente desejável. Não existe no contexto dos bate-papos são-carlense a abundância de parceiros. Não me refiro aqui ao quantitativo, mas aqueles que se encaixam no ideal de beleza, renda, raça, masculinidade, e etc., o que explica, de certo modo, o motivo pelo qual muitos dos participantes passam horas a fio sendo selecionados e selecionando um parceiro ideal. 
É interessante mencionar que os aspectos geracionais e de renda influenciam nos (des)encontros amorosos e sexuais. Constatei, por meio da interação com o campo, que aqueles que são mais novos (rapazes de até 25 anos de idade) por falta de experiências amorosas/sexuais, recursos financeiros, moradia e condições de deslocamento, acabam não se encontrando com o outro. Apesar de serem “jovens” e terem os seus corpos altamente desejados, a falta de condições materiais e subjetivas para concretizar esses relacionamentos parece marcar essa geração. De diferente modo, aqueles que são considerados mais “velhos” , geralmente, não desfrutam da possibilidade de serem fortemente cobiçados, mas estão mais dispostos a se encontrar por terem recursos, em especial financeiros. Todavia, esses “ maduros", nos termos do campo, estão “ enroscados" em compromissos profissionais e familiares. Em suma, são poucas as pessoas que concretizam os encontros marcados pelos bate-papos.

Além dos aspectos financeiros e etários, Miskolci (2013) mostra que em face da condenação moral do “meio gay”, vista como um espaço de imoralidade e promiscuidade, o negócio lucrativo que os sites de busca e relacionamentos desfrutam é o de oferecer um espaço que é supostamente limpo e que permite a seleção. Os mecanismos de buscas "atuam como filtros que permitem aos sujeitos que os utilizam, obter acesso a uma esfera moral respeitável, onde o verdadeiro e o falso, o puro e o impuro podem ser distinguidos” (p.57). Em suma, o sociólogo mostra que a purificação é a marca da seleção de parceiros em relações homoeróticas, e as mídias digitais trouxeram consigo as possibilidades de escolher, o que dá a sensação subjetiva de "limpar" a posição social legada socialmente como impura. Servem também, como vejo no meu campo, para que além de tentar se afastar da imagem da imoralidade homoerótica, as buscas se deem no intento de “apagar” as diferenças sociais vistas negativamente, tais como as raciais e de classe, ao buscar o que é reconhecido socialmente como desejável.

Quanto aos bate-papos, a diferença da quantidade de participantes varia de acordo com a dinâmica do cotidiano, que diz muito a respeito de como e quando estas salas são acessadas. No período de férias dos estudantes das duas universidades públicas instaladas na cidade, a USP e a UFSCar, o número de participantes diminui e são encontradas mais pessoas que residem na cidade. Os universitários somam quase $10 \%$ da população da cidade que tem aproximadamente 220 mil habitantes, segundo os dados do IBGE de 2010. Em termos étnicoraciais, a mesma fonte mostra que $72,3 \%$ da população é branca, 5,28\% negra, $21,56 \%$ parda 
O desejo pela branquitude e o fantasma das diferenças raciais: negociações das diferenças a partir do uso dos bate-papos na cidade de São Carlos

e $0,74 \%$ asiática, e tais números influenciam de modo perceptível as diferenças entre os participantes dos bate-papos.

Segundo minhas observações, considero que estudantes homens, a maioria vindos de outras cidades para estudar em São Carlos, tendem a desenvolver relações homoeróticas preferencialmente na localidade em que estudam, mantendo uma imagem heterossexual em suas cidades de origem. Além disso, a forte presença estudantil nos bate-papos também se relaciona ao fato de serem jovens, portanto mais afeitos ao uso das mídias digitais. Analisando os perfis existentes em um site de busca de parceiros do mesmo sexo, o Manhunt, foi constatado pelo pesquisador Rodrigo Melhado que há uma grande predominância de perfis de até 29 anos de idade e há uma grande redução no número de perfis com mais de 35 anos. Assim como observou Miskolci (2013) no contexto paulistano, pessoas que alcançaram a adolescência a partir da disseminação comercial da internet no Brasil, por volta de 1997, formam a larga maioria dos que usam meios digitais para encontrar parceiros amorosos e sexuais (p. 42).

Além disso, o que acontece na cidade, como uma simples rotina de trabalho, por exemplo, influencia nas oscilações do número de participantes. Antes do horário comercial de almoço e do fím do expediente, o número de participantes atingem facilmente o máximo do número de participantes permitidos, e torna a diminuir depois desses horários gradativamente. Após o horário de jantar, quando as pessoas estão em suas casas, após o trabalho ou os estudos, os números tornam a aumentar, e a partir da madrugada gradativamente vão diminuindo.

Estas dinâmicas quantitativas são a prova de que o modo como as plataformas estão sendo usadas diz muito a respeito do que acontece no cotidiano da cidade. Em minhas interações com os participantes nos períodos em que descrevi as oscilações, não pude precisalas com dados numéricos, já que os acessos não são fixos e variam a cada segundo. De qualquer maneira, tais dados não são os mais relevantes para essa pesquisa, a qual tem foco qualitativo e prioriza os dados dessa natureza e que podem ser recolhidos por meio da observação etnográfica. Assim, minhas anotações em caderno de campo permitem afirmar uma relação direta entre o cotidiano off-line e o uso (online) dos bate-papos de forma que seus horários de pico refletem os períodos em que a maioria não está no trabalho ou em aula.

Geralmente os acessos ao bate-papo são feitos pelos participantes em suas residências, universidades e também nos locais de trabalho que permitam o acesso à internet. Os locais de acesso formam um mosaico diverso em que cada uma de suas partes tem as suas próprias 
dinâmicas. Em minhas imersões no bate-papo um pouco antes do horário comercial de almoço ou do fim do expediente, observei e encontrei muitos participantes que estão apenas batendo um papo, assim como aquelas pessoas que buscam parceiros para fazer sexo no horário de almoço ou antes de ir para casa, o que descrevem no vocabulário corrente como “fast-foda” em uma alusão ao fast food, refeição rápida entre as atividades do dia a dia.

Os usuários destes horários costumam ter perfis diferentes das pessoas que acessam no horário noturno. Percebi nas minhas interações que, no período diurno, encontram-se residentes da cidade, casados e com filhos. Isso me faz pensar que estas interações homoeróticas devem se dar fora de alguns circuitos como o familiar, no qual devem evitar a qualquer custo que descubram seus desejos, o que lhes causaria transtornos por conta de barreiras sociais, conjugais e/ou homofóbicas. De qualquer forma, é exatamente a partir desses espaços e contextos que os homens são-carlenses fazem uso das plataformas de batepapos abrindo neles, por meio da tecnologia, uma espécie de brecha em que podem driblar constrangimentos e vivenciar online o prazer de paquerar outros homens e quiçá até mesmo conseguir transformar o flerte online em um encontro face a face.

No período noturno, é comum que uma expressiva parte dos usuários sejam universitários. Grande parte deles vindos de fora da cidade para os estudos na USP ou na UFSCar, portanto, que não moram com a família em São Carlos. Residem principalmente em bairros próximos às universidades, os quais são centrais, e moram sozinhos ou com mais uma ou várias pessoas em casas ou apartamentos que chamam de “repúblicas” ou, em termos êmicos atualmente correntes, apenas “rep” .

Os participantes que buscam relacionamentos afetivos amorosos e ou sexuais entram geralmente com nicknames (apelidos) sexualizados como "GatoSarado" , "Macho quer Macho” , “Pintudo” , “Moreno Dotado” , entre outros. Neste ponto eu poderia explorar os variados apelidos que são usados para as interações, mas me detenho em explorar somente as interações amorosas e/ou sexuais sob os critérios de cor/raça/etnia. São comuns apelidos racialmente sexualizados como “NEGÃO bom” , “MorenoCorDoPecado ” , “Negro Dotado” , “JapaQuerNamoro”, entre outros. Ao interagir com alguns participantes, o argumento utilizado para usarem estes apelidos são de que, ao mesmo tempo em que já se descrevem, com eles também facilitam que os outros participantes venham falar com eles sabendo como é a pessoa com quem se pretende falar. Vale ressaltar que os apelidos que revelam a “raça/cor” são os que trazem às palavras marcas sociais em relação ao branco. 


\section{O desejo pela branquitude e o fantasma das diferenças raciais: negociações das diferenças a partir do uso dos bate-papos na cidade de São Carlos}

Por exemplo, um homem branco não descreve sua cor/raça no apelido, a não ser que queira reforçar a sua branquitude para, assim, lhe proporcionar um maior reconhecimento erótico/social.

Percebe-se como as diferenças raciais são frequentemente verbalizadas de forma a se tornarem atributos eróticos. Alguns optam por descrever as suas características associadas às suas preferências amorosas ou sexuais. Como afirma Eva Illouz (2011), essas interações moldam as formas como estes apelidos estão desfragmentados. São " fitas métricas " (MISKOLCI, 2012a, p.5) que definem os sujeitos como fragmentos descontextualizados da totalidade da corporalidade, especialmente, no caso, voltadas para atributos como altura, peso e tamanho do órgão genital.

As conversas que são travadas nos bate-papos, com raras exceções, seguem um questionário subjetivo que é pré-definido a partir de demandas ou expectativas que envolvem a possibilidade de estender o contato online para o face a face ou off-line.

Primeiramente se cumprimentam com um “blz?” ou “ oi ”, e em seguida é perguntado a idade, localidade de onde a pessoa fala ( “de onde você fala?" ), a descrição física ( “como você é?”), quais as preferências sexuais ( “o que curte?”), e o que a pessoa busca ( "o que procura?" ). As respostas são roteirizadas: idade, bairro, cor/raça/etnia, altura, peso, cor dos olhos, cor dos cabelos, tamanho do pênis, grau de discrição da performatividade de gênero (se é “discreto” ou “afeminado”), se é “ativo” (aquele que penetra), “passivo” (aquele que é penetrado) ou “versátil” , “flex” ou “tudo” (aquele que gosta penetrar e ser penetrado), e a descrição do que a pessoa procura no bate-papo, o que é respondido muitas vezes com “o que rolar" ou “só vendo o que acontece...”. Geralmente a pessoa com quem conversa, na medida em que responde as perguntas, devolve a pergunta “e você?”.

Isto acontece de forma roteirizada e repetida nas inúmeras interações que são travadas cada vez que se conecta ao bate-papo. Se uma destas perguntas não é respondida, a interação normalmente acaba, causa indignação da pessoa que pergunta, ou é perguntada duas, três vezes a mesma coisa até que a outra responda para passar à próxima pergunta.

Acabada a “ interação-entrevista ”, se as características descritas despertarem interesse de um ao outro, segue-se uma interação em que normalmente são abertas as Webcams para a conversa (conversas com as imagens em tempo real). Outras vezes, à entrevista inicial se segue uma espécie de investigação do grau de proximidade de cada um 
NORUS - v3, n.3, jan - jun 2015.

com o círculo social do outro, pois a maioria busca um parceiro que não seja vizinho, colega de trabalho ou alguma outra coisa que implicaria em encontros e interações off-line constrangedoras. Quando um estudante da USP descobre que o outro é da UFSCar, por exemplo, especialmente de cursos bem diferentes e não moram próximos, então passam a negociar onde e quando podem se encontrar pessoalmente.

Nota-se que o “armário” , ou melhor, o regime de visibilidade, é o que rege toda a interação online e, inclusive, define o sucesso do encontro face a face. Geralmente são trocados Messenger/Skype (aplicativos de comunicação entre as pessoas que estão reciprocamente adicionados um ao outro em suas contas pessoais), pelo qual são travadas conversas fora do bate-papo. Em suma, quem chega a compor os contatos nessas plataformas, e ainda mais se há troca de telefones, passou por um processo de " filtragem " muito exigente e demorado até poder conhecer o outro pessoalmente como um potencial parceiro sexual e/ou amoroso.

Em outras palavras, a dinâmica do bate-papo é criada em meio a sua articulação com o que acontece na esfera off-line, a qual define como as relações são forjadas on-line. A esfera online, portanto, não se trata de um outro espaço, com regras próprias de sociabilidade que independeriam das cotidianas. Ela é, antes, um espaço tão criado socialmente, e definido pela cultura, quanto as relações cotidianas face a face.

Algo, no entanto, parece moldar ainda mais os contatos online do que as relações cotidianas. Trata-se da desfragmentação da corporalidade que molda as relações amorosas e sexuais mediadas digitalmente. Se no cotidiano alguém sem uma beleza padrão ou medidas modelares pode se revelar atraente, online predominam avaliações padronizadas pautadas em textos, pelas quais as pessoas se apresentam umas às outras de modo fragmentado e por medidas corporais, o que permite que as suas corporalidades sejam borradas ou alçadas de modo a tornarem-se desejáveis.

Se as medidas corporais já observadas por Miskolci (2013, p.5) como “critério da fita métrica" marcam a escolha de parceiros, considero que ainda mais - e inicialmente - entra em jogo o critério “cor/raça” . Mesmo porque os corpos racializados já se descrevem assim desde os apelidos, antes mesmo da apresentação dos dados corporais secundários (altura, peso, etc.). Vale lembrar que, no caso das plataformas de bate-papo, marcadas pela textualização dos corpos/subjetividades, os imaginários construídos em torno da racialidade em articulação com a sexualidade montam uma gramática erótica, dando contornos à maneira como as diferenças são vistas ou imaginadas. Sabemos que historicamente houve a marcação das 
O desejo pela branquitude e o fantasma das diferenças raciais: negociações das diferenças a partir do uso dos bate-papos na cidade de São Carlos

diferenças em categorizações racializantes, que são acompanhadas de uma vasta gama de adjetivações descontextualizadoras. Todas elas cristalizam e marcam, ao mesmo tempo, como estes corpos desejam e são desejados. São desejos construídos pela racialização em articulação com a sexualização.

Constatei que as imagens sociais correntes, e/ou os estereótipos étnico-raciais, definem de antemão o possível sucesso, ou relativo fracasso, nas interações no ambiente do bate-papo. Em outras palavras, a negritude tende a masculinizar e gerar expectativas de uma performatividade viril e até hiperviril enquanto a origem japonesa tende a associar o usuário a um tipo corporal e de performance desvalorizados. Claro que há a interação e as formas acionadas pelos sujeitos para modificar os termos como um negro enfatizando que não é "dotado" ou um “japonês” dizendo-se alto, malhado e viril, mas os estereótipos correntes off-line marcam e até definem o quanto as interações online podem ser benéficas aos seus respectivos interesses de encontrar parceiros.

As relações não são criadas a partir do nada nos bate-papos, visto que as forças sociais atravessam os sujeitos. São muitas as esferas sociais que devemos nos esforçar para compreender para que se torne mais nítido como e para que os bate-papos estão sendo usados na cidade de São Carlos. Para compreender os sujeitos que usam os bate-papos, fiz uma etnografia off-line em seus cotidianos para entender melhor os usos que fazem desse meio. Serão usados nomes fictícios para os meus colaboradores de pesquisa. Não irei precisar alguns dados para não expor a vida pessoal deles, de modo que não prejudique em hipótese nenhuma os meus colaboradores. Esta pesquisa toca em pontos sensíveis da vida pessoal, que está cercada socialmente pela homofobia e inclusive pelo racismo. Portanto, é um dever ético manter o anonimato dos colaboradores neste artigo.

\section{As negociações}

As buscas de parceiros em relações homoeróticas não se dá sem critérios, mas são as diferenças sociais constituídas historicamente que fundamentam as buscas desejantes. Nesse sentido, o desejo sexual, afetivo e de busca não pode ser resumido como instintivo, mas antes, o regime erótico é forjado cultural e historicamente.

Miskolci (2013) sugere pensarmos os regimes eróticos como históricos, culturalmente variados e fundamentados (principalmente) também em interesses coletivos. Nesse sentido, o sociólogo afirma que os regimes “não devem ser pensados como uma tábula rasa de sujeitos 
NORUS - v3, n.3, jan - jun 2015.

autônomos que buscam constituir relações ” (p.58), já que existem um conjunto de classificações hierárquicas que são históricas e contextuais.

Mas afinal, o que estaria regendo a busca de parceiros homoeróticos no contexto sãocarlense? Delimitar o regime erótico é uma tarefa difícil, já que conta com a colaboração de sujeitos de pesquisa posicionados de formas variadas, em suas atividades de trabalho, estudos e família. Tento, portanto, esboçar neste tópico alguns critérios de seleção e negociação de alguns colaboradores da minha pesquisa.

“Como você é?" , além de ser uma pergunta para julgar o outro segundo os seus critérios, é também para conferir se o usuário é uma pessoa conhecida das suas interações, bem sucedidas ou frustradas. Nem sempre as mídias digitais são usadas como esperado comercialmente ou de modo padronizado em todos os lugares, pois existem as apropriações contextuais que mostram como os seus usos são variados e ambientados em contextos sociais localizados, como o do interior paulista.

O que, então, rege a busca? Qual seria o regime erótico no contexto são-carlense? Para compreendermos um contexto social onde a desigualdade é a marca das diferenças sociais, se faz necessário designar alguns eixos para que, a partir dos colaboradores de pesquisa, possamos compreender os imprecisos contornos de um regime erótico que controla os códigos pelos quais se dão os relacionamentos amorosos/sexuais.

Miguel tem 24 anos de idade, já possui uma graduação e mora em um bairro próximo a uma universidade pública, onde faz pós-graduação. Veio para São Carlos de uma cidade pequena do Paraná onde morava sozinho por motivos de estudo e trabalho. Embora estivesse morando sozinho, sempre se encontrou com a sua família, que é composta por seis membros que trabalham afastados do centro urbano.

Por ser muito raro que alguém “japa” entre no bate-papo não hesitei em interagir com ele. Depois de trocarmos as informações gerais básicas exigidas nas interações, informeilhe que sou pesquisador e perguntei sobre o seu interesse de colaborar com a pesquisa. Prontamente se dispôs a ajudar no que fosse preciso. Afirmou que por eu também ser um “japa” assim como ele, não poderia deixar de contribuir com a pesquisa, e tal fato ajudou para que a nossa interação pudesse ter sido firmada.

Em uma interação que tive com outro rapaz que se considerava “ japa” , não pude contar com a mesma sorte. Por ele ser uma pessoa que frequenta espaços sociais da “ comunidade japonesa” da cidade de São Carlos, a desconfiança de que eu poderia conhecer outros “japas” não lhe agradou - já que as pessoas do seu círculo social não 


\title{
O desejo pela branquitude e o fantasma das diferenças raciais: negociações das diferenças a partir do uso dos bate-papos na cidade de São Carlos
}

sabem que ele se relaciona sexualmente com outros homens - e afirmou acreditar que eu poderia prejudicá-lo caso conhecesse alguém que também o conhecesse, mesmo eu lhe informando que a pesquisa seria sigilosa. Diferente de Miguel, que chegou a São Calos recentemente (no ano de 2013), para quem este “risco” temido pelo outro rapaz é menor, já que ele não faz parte do círculo social de outros nipodescendentes locais. Os seus temores, porém, são de outras ordens, como a de que as informações a seu respeito chegassem aos ouvidos de quem faz parte do seu círculo social universitário.

As minhas interações com Miguel, criadas a partir do bate-papo, se intensificaram ao conversarmos frequentemente pelo Skype, o que permitiu que pudéssemos sair juntos a um café, para conversarmos melhor sobre diversas questões, inclusive sobre a sua percepção sobre a sexualidade, família, amigos, etc., o que nos ajuda a compreender o que rege a busca de parceiros no contexto são-carlense.

Em uma das conversas o colaborador conta:

\begin{abstract}
Minha família não tem conhecimento da minha sexualidade, embora eu acredite que eles sempre souberam que eu sou homossexual, devido ao meu diferente comportamento em relação aos meus irmãos. Quanto a ser uma família japonesa, eu acredito sim que seja diferente, aliás, acredito que em todas as famílias essa questão do homossexualismo (sic) é diferente. Minha família nunca falou sobre sexo ou relações afetivas com pessoas do gênero feminino ou do gênero masculino [...]. Por eles serem tímidos, isso já leva a outra questão: eles são bem preconceituosos em relação a homossexuais. Meu pai uma vez me falou que iria ter vergonha de ter um filho ladrão ou de ter um filho que causasse algum escândalo para ele. Eu tenho certeza que a minha sexualidade seria um escândalo para ele [...]. Eu já tive muito mais contato com meus irmãos quando eu era criança/adolescente, naquela época eles discriminavam muito os homossexuais, com palavras ofensivas mesmo, do tipo "viadinho", "bichona” , "bibinha” , "boiola” , enfim, estes atributos que a população costuma denominar os homossexuais. [...] Minha família é muito tradicional, por isso, para eles tudo tem de ser muito igual, homem casar com mulher e depois filhos, netos, bisnetos e morte. Eu tenho primos que todas as vezes que me encontram sempre perguntam: E as namoradinhas? Tá comendo quantas? Pegou alguma aluna sua? Tem que honrar o nome da família Miguel... Acredito que todos eles são assim justamente por estarem em círculos sociais onde o homossexualismo (sic) não é comum ou frequente. Todos eles são agricultores, o contato com pessoas desse círculo social é sempre muito tradicional, tanto que as conversas sempre são as mesmas: Quantas terras vai comprar, como vai colher, quando vai colher, negócios da agricultura, enfim, não há contexto para assuntos como relações afetivas e sexualidade.
\end{abstract}

Miguel teme decepcionar a sua família por conta de sua sexualidade, não atendendo as expectativas de que case com uma mulher e tenha filhos. Percebe que a sua família é preconceituosa por conta das interpelações que o atingiram e ainda atingem, forçando-o a vivenciar a sua sexualidade na vergonha, medo e segredo. Este é um dos motivos pelos quais 
NORUS - v3, n.3, jan - jun 2015.

Miguel visualiza que viver longe da família é mais fácil. Foi apoiado pela sua família para seguir a carreira universitária no curso na área de Engenharia, mas fica em dúvidas se terá o mesmo apoio quanto a sua sexualidade. Por estes motivos Miguel prefere viver a sua sexualidade longe de sua casa. Para ele “essa questão de morar sozinho em São Carlos foi mais por motivos de que eu prefiro mesmo morar sozinho, e de que eu não conheço ninguém na cidade” .

Nas cidades pequenas, como onde Miguel morava (3.000 habitantes), o controle social regula - e até impede - de forma mais efetiva a vivência da homossexualidade. São Carlos tem mais de 220 mil habitantes, portanto é bem maior, e é um local onde há menores possibilidades de ser conhecido por “ todos” (amigos e família), o que torna mais fácil negociar interações sexuais em sigilo. A densidade de pessoas e as formas de comunicação em seu maior grau podem afrouxar as formas de controle tradicional e vínculos afetivos familiares e de amizade, possibilitando uma manipulação pessoal dos códigos do armário segundo seus interesses pessoais. Em São Carlos, Miguel é anônimo. Seu caso ajuda a perceber que existem diferenças entre cidades de tamanhos diferentes.

Miguel nunca teve relações afetivas/sexuais com alguém que conheceu fora da internet (bares, praças, baladas, festas, etc.). Conta que em sua pequena cidade, ninguém que era homossexual flertava com outro num ambiente de interação social, em suas palavras, “devido ao alto preconceito e rejeição à diversidade sexual” . A generalização do receio de Miguel, de que todas as pessoas da cidade onde morou são preconceituosas, se torna compreensível quando ele conta que o que mais tem receio, é de que seus amigos e familiares fiquem sabendo. Trata-se, portanto, apenas de uma sensação de Miguel, o que não quer dizer que São Carlos seja menos homofóbica, mas antes, uma cidade afastada de seus vínculos sociais importantes, como a sua família e amigos.

$\mathrm{Na}$ perspectiva de Miguel, a internet sempre o ajudou a se relacionar com outros homens, afastando-o, segundo ele, de um “ambiente homofóbico” , pois, para ele, é muito mais fácil se relacionar com as pessoas pela internet, visto que se tem mais tempo de pensar em respostas por não estar pessoalmente com a pessoa e, assim, sente-se mais à vontade e livre para dizer o que quer, justamente pelo fato da timidez atrapalhar nos encontros off-line. A internet, nesse sentido, ajuda Miguel se relacionar com outras pessoas sem que a sua corporalidade, envolvida nas interações face a face, prejudique suas relações. Illouz (2011) afirma que na interação face a face a visão holística que se tem do outro prepondera, ao contrário de quando uma pessoa se fragmenta em textos na internet. Neste sentido, Miguel 


\section{O desejo pela branquitude e o fantasma das diferenças raciais: negociações das diferenças a partir do uso dos bate-papos na cidade de São Carlos}

pode borrar partes de sua corporalidade que o prejudiquem, por exemplo, evitar tornar evidente ao outro que as suas mãos tremem por ser tímido.

Miguel afirma que costuma usar os bate-papos por ser a forma mais rápida de encontrar o que realmente procura. Segundo ele:

\footnotetext{
Você conhece a pessoa, marca o dia, local e hora para sexo ou adiciona a pessoa em alguma rede social para manter amizade. Costumo utilizar também alguns sites de relacionamento como o Facebook, o quase extinto Orkut, sites como o "par perfeito" também. Em questão desses sites de relacionamentos eu acho até melhor, pois você já consegue ter noção de como a pessoa é, devido às fotos, os gostos pessoais, o porte físico e outros recursos que os sites disponibilizam. Nos bate-papos busco sexo, amizade ou informações que necessito com maior urgência.
}

O colaborador evidencia que usa diversas plataformas com intenções diferentes, algumas para relacionamentos amorosos, e outras sexuais. Para Miguel, sites como Facebook, Orkut e Par Perfeito disponibilizam ferramentas para postar e visualizar fotos, vídeos, e outras referências, o que permite que as pessoas tornem as suas imagens pessoais mais nítidas e autênticas, dando a sensação de seriedade que permite a ele buscar relacionamentos amorosos. Penso que, o que dá essa sensação de “seriedade” não são apenas as ferramentas que estas plataformas de buscas e relacionamentos oferecem para tornar as pessoas mais “verdadeiras”, mas, principalmente, porque a nitidez da imagem do outro diz respeito àqueles inseridos na esfera pública, que é historicamente reservada à heterossexualidade. Neste raciocínio, as pessoas que desejam outras pessoas do mesmo sexo abertamente em um ambiente presumidamente heterossexual, não estão em paranoia constante, calculando os riscos já que, para estes, o “armário” não rege de forma profícua as formas como podem se relacionar, o que abre outras possibilidades de relacionamento como o amoroso. Deste modo, Miguel consegue achar nessas plataformas outros homens para se relacionar, possivelmente de forma amorosa e não apenas sexual, como acontece na maioria das vezes nos bate-papos.

Não faz sentido perguntar para um homem que se relaciona abertamente com outros homens se alguém sabe da sua sexualidade. O contrário se passa nos bate-papos, que são usados como uma das melhores plataformas para se relacionar em segredo. Na maioria das vezes, quem usa os bate-papos não quer um relacionamento amoroso e duradouro, não porque só se interessem pelo sexo, mas porque não têm condições para vivenciarem publicamente relações homossexuais. De que outra forma, homens que tentam viver “ heterossexualmente", poderiam se relacionar com outros homens com o máximo de 
NORUS - v3, n.3, jan - jun 2015.

discrição? Não é criando relacionamentos amorosos e duradouros, mas antes, priorizando encontros sexuais sem compromisso.

Pude compreender a partir de Miguel que na cidade de São Carlos é possível se relacionar homoeroticamente com outros homens de uma forma mais anônima e sigilosa em relação às cidades de menor porte. $\mathrm{O}$ fato de Miguel ter vindo de outra cidade, permite a ele se relacionar com outros homens sem criar situações desagradáveis com a sua família e amigos próximos. O colaborador aponta para uma maior praticidade que as mídias digitais oferecem para se relacionar homoeroticamente, mas devo pontuar que ele não se encontra casualmente com outros homens por ter critérios de seleção rígidos, tais como raciais, escolaridade e “gostos” . Pelas minhas observações, ele passa horas a fio, até mesmo meses até encontrar alguém “ relacionável” , ou seja, alguém como similaridades sociais, ou até mesmo, mais valorizadas socialmente.

Desta forma, é possível compreender que, embora possa existir uma aparente praticidade, se faz necessário um grande empreendimento nas buscas de parceiros. $\mathrm{O}$ que compõe a lógica do uso dos bate-papos no contexto são-carlense, portanto, não é a praticidade nem a abundância. $O$ uso dessa mídia se mostra socialmente ineficiente, e a escassez de parceiros é a consequência do excesso de critérios de seleção. Já os relacionamentos que são feitos em segredo não são, muitas vezes, consumados pessoalmente, já que isso pode implicar altos custos psíquicos e sociais, por estarem ambientados fora da proteção das mídias digitais.

Geralmente as pessoas respondem em um intervalo de tempo curto, pois, com o volume de conversas geradas pelos participantes, a abordagem feita por outrem - visto que entram e saem participantes a todo o momento das salas - se “perde" em meio às conversas de outras pessoas, impossibilitando a resposta quando a pessoa já se encontra desconectada. O estranho é que Juliano, 21 anos, que atendia no chat pelo apelido de “Negro21HxHAfim” , me respondeu somente quase uma hora depois que o abordei. $\mathrm{Na}$ nossa interação inicial, compreendi que Juliano estava conectado ao bate-papo em seu local de trabalho e que às vezes, dependendo da intensidade do serviço, poderia demorar para responder.

Fiquei surpreendido com os métodos de negociação de Juliano, que são pontualmente calculados e otimizados para ter maior sucesso em suas interações nos bate-papos. De forma meramente esquemática, tento ilustrar no quadro que segue os apelidos que o Juliano sempre usa nos bate-papos (Negro21aHxH, Negro21aHxHc/local, Negro21aHxHc/localAfim): 
O desejo pela branquitude e o fantasma das diferenças raciais: negociações das diferenças a partir do uso dos bate-papos na cidade de São Carlos

\begin{tabular}{|c|c|c|c|c|c|}
\hline APELIDO/NICKNAME & Negro & $21 \mathrm{a}$ & $\mathrm{HxH}$ & $\mathrm{c} /$ local & Afim \\
\hline QUANDO USA & Sempre & Sempre & Sempre & $\begin{array}{ll}\text { Quando está } & \text { em } \\
\text { serviço, pois } & \text { tem } \\
\text { possibilidade de fazer } & \text { sexo sigilosamente no } \\
\text { seu ambiente } & \text { de } \\
\text { trabalho } & \\
\end{array}$ & Quando o sexo é urgente \\
\hline $\begin{array}{l}\text { QUEM } \\
\text { INTERAGIR }\end{array}$ & $\begin{array}{l}\text { Aqueles que gostam de } \\
\text { “ negros ” por } \\
\text { imaginarem que são } \\
\text { másculos, safados, com } \\
\text { “pegada” e pênis } \\
\text { grande }\end{array}$ & $\begin{array}{l}\text { Aqueles que } \\
\text { gostam de } \\
\text { jovens }\end{array}$ & $\begin{array}{lr}\text { Homens } & \text { que } \\
\text { desejam } & \text { se } \\
\text { relacionar } & \text { com } \\
\text { outros homens } & \end{array}$ & $\begin{array}{l}\text { Aquelas pessoas que } \\
\text { procuram alguém com } \\
\text { um local sigiloso para } \\
\text { fazer sexo }\end{array}$ & $\begin{array}{l}\begin{array}{l}\text { Aqueles que também } \\
\text { querem }\end{array} \\
\text { imediatamente }\end{array}$ \\
\hline $\begin{array}{l}\text { QUEM NÃO } \\
\text { INTERAGIR }\end{array}$ & $\begin{array}{l}\text { Pessoas que não } \\
\text { gostam de “negros” }\end{array}$ & $\begin{array}{l}\text { Aqueles que } \\
\text { curtem } \\
\text { apenas } \\
\text { pessoas } \\
\text { mais velhas }\end{array}$ & $\begin{array}{l}\text { Heterossexuais } \\
\text { mulheres }\end{array}$ & $\begin{array}{llr}\text { Pessoas } & & \text { com } \\
\text { insegurança } & \text { ou } & \text { sem } \\
\text { condições } & \text { de } & \text { se } \\
\text { deslocar } & & \end{array}$ & $\begin{array}{l}\text { Pessoas que estão } \\
\text { apenas conversando no } \\
\text { bate-papo ou buscando } \\
\text { relacionamentos } \\
\text { estáveis }\end{array}$ \\
\hline
\end{tabular}

QUADRO 1 - EXPLICAÇÃO DE JULIANO SOBRE SEU O APELIDO QUE USA NO BATE-PAPO.

FONTE: O autor (2013).

Juliano não aborda ninguém, mas ao contrário, espera que as pessoas venham conversar com ele. Calcula ele que isto aumenta $50 \%$ as chances de que a relação se desenvolva para algo que ele queira. Explica que se ele faz a abordagem, corre riscos de que a pessoa não responda ou diga que não gosta das características descritas em seu apelido, mas se os rapazes vêm abordá-lo é porque algo os atraiu, portanto aumenta as suas chances de desenvolver alguma relação com estas pessoas. A descrição de seu apelido, portanto, serve como um filtro para pessoas com quem se relaciona, o que aumenta a possibilidade de que algumas destas relações se desenvolvam para os encontros pessoais.

O colaborador diz ser ciente que muitas pessoas não gostam de “ negros", e explicitar isto em seu apelido é a forma pela qual ele filtra aqueles que gostam daqueles que não gostam de sua racialidade. Juliano conta que, às vezes, o fato dele ser “negro" e explicitar isso em seu apelido se torna um obstáculo quando ele apenas procura conversar e fazer amigos. Na maioria das vezes, por visualizarem que ele é “ negro” , o abordam imaginando uma pessoa hipersexualizada. Não é incomum perguntarem a ele, antes mesmo de cumprimenta-lo, quantos centímetros tem o seu pênis, se é malhado, se tem pegada, e etc. Juliano afirma não ter muitas dessas características, mas muitas vezes quando ele quer sexo consegue facilmente, por conta de sua racialidade que desperta curiosidades e fetiches. Mas afinal, se às vezes o atrapalha, por que não troca de apelido quando isso acontece?

Para Juliano, trocar o apelido traria mais consequências negativas do que positivas. Segundo o seu raciocínio, a maioria das pessoas que entram nos bate-papos o fazem com os mesmos apelidos com pouquíssimas variações. O colaborador afirma que já esteve em uma sala de bate-papo onde conseguiu identificar 25 dos 30 participantes. Isto é um aspecto positivo para ele, pois identificando estas pessoas, evita que ele perca o seu tempo falando 
NORUS - v3, n.3, jan - jun 2015.

com aqueles com quem já conversou e não gostou. Juliano utiliza o mesmo apelido não por ter compaixão com os outros usuários que tentam evitá-lo, mas antes, para que algumas pessoas consigam encontrá-lo. Muitas pessoas, geralmente aquelas comprometidas com a imagem “heterossexual”, evitam deixar vestígios de suas interações, ou seja, sempre entram nos bate-papos escondidos da família e dos amigos e não trocam contatos como número de celular, Skype ou Facebook, como uma forma de impossibilitar que alguém com quem já se relacionou homoeroticamente venha prejudicar a sua “heterossexualidade” . Para entrar no bate-papo, é apenas necessário que a pessoa coloque um apelido e faça as suas interações, ou seja, é mais prático e sigiloso. Ao usar o mesmo apelido, Juliano possibilita que as pessoas que evitam trocar contatos, para não deixar seus rastros, possam voltar a encontrar o “Negro21aHxHc/localAfim” depois de alguns dias, ou até semanas, para continuar as conversas não acabadas. Isto cria, até mesmo, a possibilidade de reencontros amorosos e sexuais, caso a pessoa tenha gostado e venha abordá-lo novamente. Em suma, é Juliano quem deixa rastros para facilitar estes reencontros.

Dependendo de como os seus desejos se direcionam, Juliano afirma que ou sente vontade de ser “ativo", aquele que penetra, ou de ser “passivo”, aquele que é penetrado. As pessoas que o abordam no bate-papo expressam preferências de posições sexuais variadas e Juliano explica aos rapazes que é versátil, mas que procura se relacionar, naquele momento, em uma posição sexual determinada. Ao invés de selecionar somente aquelas pessoas que ele deseja naquele momento, troca contato com todos, independentemente das posições sexuais. Esta é a forma que Juliano encontrou para compor um banco de contatos "reserva” em seu Skype, para que quando estiver desejando outras formas de relações sexuais, possa selecionar em seu “menu” os rapazes com quem quer interagir.

Juliano usa as plataformas de internet para criar, em sua maioria, contatos reais, de forma que o on/off-line "se dão dentro de uma dinâmica articulada e interdependente" (MISKOLCI, 2012a, p.3). Segundo Miskolci, a internet é uma ferramenta que permite a formação seletiva de redes relacionais, de forma que o que se passa online não pode ser facilmente subsumido às formas de sociabilidade off-line habituais, como cafés e bares, nos quais temos contato limitado e “obrigatório” com as pessoas próximas a nós. Na internet se criam redes de sociabilidade baseadas na escolha das pessoas com quem queremos interagir. Ainda segundo o autor, a internet possibilita, por exemplo, a possibilidade de paqueras múltiplas ao mesmo tempo. Beleli $(2012$, p.59) complementa esta reflexão nos mostrando que 


\section{O desejo pela branquitude e o fantasma das diferenças raciais: negociações das diferenças a partir do uso dos bate-papos na cidade de São Carlos}

na internet se tornou possível interagir na paquera com uma ou várias pessoas ao mesmo tempo, livre das condenações morais que aconteceriam em espaços cotidianos off-line.

Segundo Illouz (2011), a tecnologia da internet funde as lógicas culturais da psicologia e do consumismo. As plataformas de interação on-line solicitam que as pessoas sejam reflexivas de modo a pensar como tornar o "eu" (self) público por meio de uma textualização da subjetividade. Este modelo de textualização de si faz com que o conhecimento que se tem das pessoas preceda a atração, ou seja, sob a égide da ideologia liberal da escolha as pessoas racionalmente se textualizam e escolhem com quem querem se relacionar. Esta lógica coloca as pessoas nessas plataformas em competição umas com as outras. Segundo Illouz (2011), nessas plataformas, o “eu” é orientado para um público anônimo, o que exige uma padronização das descrições de si. Paradoxalmente, a autora nos mostra que são aquelas pessoas que têm uma originalidade linguística as que têm sucesso. Diante do volume das interações, assim como para maximizar opções custo-benefício, emerge uma roteirização das perguntas e até das descrições de si mesmo/a. Em outras palavras, segundo a socióloga marroquina, a internet acaba por racionalizar a escolha de parceiros, já que o vocabulário dos afetos nela é marcado pelo mercado.

No entanto, o que faz com que Juliano use o mesmo apelido, ao contrário do que diz Illouz, embora pareça seguir a lógica de abundância, não o é. O colaborador usa o mesmo apelido para que as pessoas o reencontrem, assim como, também, para driblar preconceitos raciais. A princípio Juliano não escolhe, mas espera ser escolhido entre muitos outros participantes. Não é possível afirmar que Juliano faça isso por conta da abundância de participantes nos bate-papos, mas motivado pelo contexto social homofóbico e racista em que está inserido. Illouz parece falar de um contexto onde todas as pessoas são iguais e todos podem escolher, o que não acontece no meu campo.

Já o meu colaborador de pesquisa Ricardo, 21 anos, universitário, que faz o uso frequente dos bate-papos, faz uma criteriosa seleção de parceiros. Para ele, assim como a idade e o peso, a racialidade é um critério de seleção. Pedi para ele fazer a distinção daqueles que ele se relacionaria e não se relacionaria, e mostrou sistematicamente que: "Olha japa, anota aí. Não curto japa, desculpa. Moreno, moreninho, gordo, velho, muito novo, afeminado, cabeludo, barbudo, índio, magro demais e pessoas burras. Eu curto pegar uns caras como eu, bonito." Ao mesmo tempo em que o Ricardo gosta da ideia de que tenha bastante pessoas que o deseje nos bate-papos, se queixa do trabalho de selecionar: "Pô, quando eu acho que finalmente consegui alguém, é feio, vizinho, afeminado. E olha que eu me esforço heim! ” 
NORUS - v3, n.3, jan - jun 2015.

Pelas minhas observações, o Ricardo entrava nos bate-papos geralmente às 8 horas da noite e saía somente de madrugada, selecionando alguém para se relacionar. Somente quando se esgotava a possibilidades de seleção, já tarde da noite, Ricardo passava a falar comigo, sempre atribuindo o insucesso ao outro.

Podemos concluir, a partir das experiências de Miguel e de Juliano, que o segredo é o principal atrativo do uso dos bate-papos, pelos quais os critérios de seleção de parceiros se dão sob o regimento de padrões valorizados socialmente, tais como a branquitude. $\mathrm{O}$ que rege a busca não é, portanto, a praticidade - como vimos também no caso de Ricardo. Em uma sociedade com menos desigualdade social talvez faça algum sentido, mas em São Carlos a lógica do uso se dá a partir do segredo e das negociações das diferenças ordenadas hierarquicamente.

Em suas interações nos bate-papos, Miguel usa o nickname “japa” , pois para ele é a forma mais fácil de encontrar pessoas que têm afinidades com nipônicos. O fato interessante é que, assim como o colaborador de pesquisa Juliano, Miguel também não aborda o outro usuário para a conversa, mas prefere esperar: "Você não precisa chamar algum usuário, este usuário vai até você, então é mais cômodo. Já descrevi que eu sou japonês e, com certeza, a pessoa que vai me abordar curte japoneses.” Miguel costuma usar outros apelidos como João, Pedro, Jorge, mas quando apenas quer “jogar papo fora” . Isto mostra que o colaborador é ciente das vantagens e desvantagens do uso de sua racialidade, preferindo usá-la quando o intuito é criar relacionamentos reais, tornando as pessoas cientes de sua racialidade logo no início, o que evita futuras frustrações.

Miguel tem a impressão de que São Carlos é uma cidade de muita diversidade devido aos universitários, então acredita que a procura por japoneses é maior. Sempre que se agencia com o apelido “japa” espera que as pessoas pensem "Huuum japinha, vou teclar com ele para saber o que ele quer, se ele quer o que eu quero" . Para ele é uma questão de esperar pessoas que tenham desejos ou afinidades com “orientais” virem abordá-lo. Ao questionálo sobre o que ele imagina que as pessoas pensam quando ele se diz “japa” , afirma que:

Com certeza, 90\% delas imaginam um rapaz de olhos puxados, gordinho, de estatura média, que possui um pênis pequeno e que é passivo na relação sexual. Isso quando se trata de sexo. Para amizades, eu acredito que seja mais pelo fato da fama do japonês ser inteligente e pela cultura japonesa ser tão admirada pelas outras culturas. 


\section{O desejo pela branquitude e o fantasma das diferenças raciais: negociações das diferenças a partir do uso dos bate-papos na cidade de São Carlos}

Diz ter a impressão de que as pessoas acham um japonês muito metido, que não dá atenção, e não atraente fisicamente. Mas pelo contrário, visualiza que algumas pessoas admiram os “japoneses”. Explica:

Acredito que pela cultura dos japoneses, pela história que eles passaram, pelo menos é essa conclusão que eu tenho dos anos de bate-papo que eu vivenciei. As pessoas gostam da cultura japonesa, da forma como eles priorizam a educação. Outras pessoas querem tirar a curiosidade sobre como é transar com um japonês, outras pessoas simplesmente perguntam sobre aspectos físicos. Mas a maioria que já conversou comigo sentem (sic) atração física, porém nunca conseguiram ficar com um japonês na vida real.

“Japa” se descreve no bate papo como alguém de “ $1,68,60 \mathrm{~kg}$, branco, cabelos pretos lisos, olhos castanhos escuros, bonito, flex mais passivo, e que procura um papo bom e o que rolar a mais é lucro" . Conta que, não bastando a sua descrição, é na conversa e pela sua imagem de câmera que conquista parceiros. "Outra coisa é o papo que eu tenho com o outro usuário. As pessoas se encantam com o tipo de diálogo que eu tenho e depois se sentem mais atraídas quando me veem pela webcam” .

Miguel usa os seus diálogos criativos e a ferramenta de vídeo on-line, disponibilizada pelo bate-papo, para se livrar de algumas exotizações, provando na sua fala que é uma pessoa legal, e pela imagem que não é um “ gordinho, de estatura média, que possui um pênis pequeno” . É usando a conversa criativa e os recursos multimídia que Miguel consegue

“descolar-se” dos estereótipos, pois assim a realidade substitui de certa forma o imaginário do que seria um “japa:

Gosto de pessoas que tenham um estilo comum ao meu, que gostam de animais, principalmente cães, que leia livros, vivam no ambiente universitário, no ambiente de pesquisas, que me entenda, que goste de assistir séries, filmes, de ir a barzinhos, reunião de amigos, não daquelas pessoas que curtem baladas, raves, cervejadas. Enfim, sou bem tranquilo neste sentido, e procuro uma pessoa tranquila também, como eu. Um namorado ideal combinaria todas essas características.

Miguel, no entanto, afirma que “ com japoneses eu sempre opto por amizade, pois diferentemente de outras raças, com japoneses eu já consigo prever como seria a relação, então, realmente não daria certo" . Se relacionar com pessoas com similaridades sociais e de gostos o satisfaz, o que mostra que o colaborador de pesquisa deseja da forma como se é esperado socialmente, ou seja, com pessoas que tenham experiências similares, e, neste caso, 
NORUS - v3, n.3, jan - jun 2015.

Miguel demonstra querer se relacionar com uma pessoa “certinha”, que cursa pósgraduação e que seja "caseiro” .

O colaborador expressa não querer se relacionar amorosamente com outros "homens japoneses” . Miguel diz prever como seria uma relação com outro “japa” , o que, para ele, não daria certo. Isto torna evidente que os estereótipos, subjetividades e corporalidades forjadas nos sujeitos “japoneses” pelo processo de sexo-racialização não o agradam. A ideia de que ele e o seu possível parceiro seriam hierarquizados negativamente na mesma “identidade” faz Miguel concluir que “De japa, já basta eu!” .

Em análise feita sobre “Cor/raça, gênero, sexualidade e sociabilidade juvenil no centro de São Paulo” , por Simões, França e Macedo (2010), torna-se compreensível como se articulam as diferenças sociais com a sexualidade. Simões et. al. começam elucidando que as diferenças são marcadores de sistemas classificatórios. Estas categorias " definem-se umas em relação às outras, além de atravessarem e circularem por diferentes relações ” (p.40) tornando-se sujeitos e atores sociais. A interseccionalidade torna-se, portanto, uma linguagem que expressa hierarquias e desigualdades.

Há uma constatação interessante em relação aos rapazes negros deste estudo que pode ampliar significativamente a nossa compreensão: marcadores como cor/raça combinam-se a outros marcadores, como a masculinidade. Simões, França e Macedo (2010), constatam que a combinação entre estilo de vestimentas como boné, camiseta regata justa, bermudão e jeans, mais um tipo físico alto e musculoso, com performance de gênero masculina hegemônica e a cor da pele escura produz a figura do “negão", que normalmente gera expectativas relacionadas a “tamanho de pênis, potência e desempenho sexual acima da média” (p.53). Caso a negritude seja associada a uma performance de gênero oposta à do “negão” , ela passa a sugerir o uso de classificações como as de “bicha-preta” , ou “bicha close” , que são desvalorizadas eroticamente. De forma preliminar, é possível reconhecer que existem formas peculiares de normatização no nosso país que são reforçadas pelos múltiplos dispositivos sexo/raciais.

Juliano afirma que se identificar com “ negro", o ajuda a arranjar parceiros homoeróticos. Conta que não é tão difícil encontrar parceiros sexuais por conta disso, mas, quase sempre, é requisitado a desempenhar um papel dominador e penetrador em suas relações. Por outro lado, se sente frustrado por conta desse estereótipo de “negão” quando 
O desejo pela branquitude e o fantasma das diferenças raciais: negociações das diferenças a partir do uso dos bate-papos na cidade de São Carlos

quer ser penetrado ou arranjar parceiros amorosos. Ser reduzido a um "ser sexual” nem sempre é vantajoso para Juliano.

É preciso tomar cuidado para não associar o “estilo” de Juliano com a figura do “negão” . O colaborador se veste com camiseta colada ao corpo, calça jeans, tênis, às vezes usa uma corrente metálica no pescoço e faz academia. Muito pelo contrário, Juliano não se compreende como se fosse um “negão" por conta da forma como se estiliza. Para ele, tem a ver com a questão, unicamente, de classe, e não por conta de sua racialidade. Juliano afirma que, se ele se veste mal, as pessoas ficam olhando "torto" , e que poderiam confundi-lo com um mendigo, maloqueiro ou bandido. Para se desvencilhar dessa associação usa roupas caras, de forma que tenha "livre acesso" para frequentar qualquer lugar e ser respeitado.

Embora ele afirme que a forma como se veste não tenha nada a ver com a sua racialidade, acredito que a forma como Juliano se estiliza tenha a ver com “classe” em articulação com suas experiências sociais racializantes que foram subjetivadas e interpretadas por ele como uma violência de classe. Ao contrário da forma como ele se agencia nos batepapos, se essencializando como negro, no contexto off-line Juliano tenta borrar suas marcas de classe, coladas histórica e socialmente à sua racialidade, se estilizando de forma com que a sua “cor” se apague.

Embora sejam considerados como pressupostos, os meus colaboradores "brancos" descrevem a sua cor na interação, e mais raramente, se descrevem serem brancos logo nos apelidos. Mas se são pressupostos, por que descrevem a sua cor? Pelas minhas observações, ser “negro” ou “moreno” pode até trazer ganhos eróticos, mas é improvável que estes sempre sejam os corpos idealizados como desejável no contexto são-carlense. Onde o pressuposto é ser “branco” , uma pessoa pode até desejar um “não-branco” , mas é mais provável que os desejos estejam de acordo com o que é socialmente desejável.

Guilherme, 25 anos, universitário, um de meus colaboradores de pesquisa não se considera "branco" , mas se descreve como tal para buscar parceiros nos bate-papos: “Olha, eu acho que não sou branco. Na verdade não sei o que sou. Mas se eu falo que sou branco, as pessoas não questionam e curtem na boa”. O Guilherme se agencia como "branco", e ele tem a consciência do que é preciso para ser considerado como tal. O colaborador elucida em sua fala: "Diz aí, você acha que se eu andasse de bicicleta e tivesse uma cor um pouco mais escura eu ia poder dizer que sou branco? Eu ia ser só baiano pelo 
meu sotaque. [...] Para ser fita a gente tem que se esforçar. A gente é várias coisas ao mesmo tempo, para não parecer o pior a gente tem que ser o melhor”. Instigado com a sua fala, o provoquei: “Mas tá, então é só ir para a academia, comprar um carro e ter grana? Se é assim, tá fácil para qualquer um” . Para o Guilherme, não se trata de apenas ter músculos, carro e dinheiro, pois estas coisas em si não constituem um "branco" : “O que você fala não tem nada a ver pô. Não basta ir para a academia e não saber se mostrar depois. Não adianta ter grana e fazer coisa de pobre. Não adianta ter carro e não saber andar nele mascando o chiclete igual um playboy” . Neste sentido nem todos podem ser “brancos” de uma hora para outra.

Ser "branco" não é apenas a cor da pele, mas antes conta com outras características coadunadas no corpo. Em suma, não é possível localizar a branquitude em um “branco” , mas ela paira sobre os corpos como um desejo.

Miskolci (2012b), em seu estudo sobre a masculinidade e branquitude no Brasil de fins do século XIX, mostra que a branquitude "é um ideal criado pelas elites brasileiras entre o final do XIX e o início do século XX, o qual adquire mais importância no regime republicano" (p.51). A branquitude, portanto, era um “ideal presente em vários discursos, dos políticos aos médicos e literários, os quais encontravam nela um denominador comum do desejo da nação, valor fundamental que guiava as demandas elitistas de branqueamento de nosso povo” (p.51). Branquear não era, continua o autor,

Apenas ou exatamente um projeto de transformação demográfica, mas também - e principalmente - de moralização da coletividade. A despeito de seu foco em toda a população, tratava-se de um desejo das elites dirigentes, esmagadoramente formada por homens, e que interpretavam a branquitude como um valor próprio que a caracterizava e distinguia do povo. (MISKOLCI, 2012b, p.51).

A branquitude, no entanto, não se refere à questão da cor da pele unicamente, ela diz respeito aos poucos homens brancos de elite que dirigiam a nação. Neste sentido, " ser branco e pobre era um oximoro, por isso as classes populares eram vistas como ignorantes, imorais, e até 'selvagens' .” (p.51). As teorias e as práticas higienizadoras não visavam, segundo Miskolci, melhorar a vida das classes populares, mas antes, a "constituição de um cordão sanitário entre elas e as classes altas” (p.51).

O importante da reflexão suscitada por Miskolci (2012b) é considerarmos que a branquitude não é somente a cor da pele, mas um conjunto de atributos sociais e morais. A 
O desejo pela branquitude e o fantasma das diferenças raciais: negociações das diferenças a
partir do uso dos bate-papos na cidade de São Carlos

branquitude não pode ser naturalizada como uma característica de uma pessoa que tem a cor da pele branca, pois, a pobreza, por exemplo, pode até mesmo “enegrecer” os sujeitos.

O branco é, no caso dos meus colaboradores de pesquisa, um ponto de identificação o qual melhora a sua imagem socialmente. Reitero novamente que não estou de modo algum pensando em uma identidade coletiva, mas antes um ponto de identificação - a branquitude

- e isto nos ajuda a compreender as enunciações discursivas que partem dali.

As identidades são, portanto, construídas “dentro e não fora do discurso ” , elas “ emergem no interior do jogo de modalidades especificados do poder e são, assim, mais o produto da marcação da diferença e da exclusão” (HALL, 2008, p.109).

\section{Algumas considerações}

Os meus colaboradores de pesquisa estão sempre sozinhos, buscando alguém que nunca encontram, e que, quando encontram, são pessoas “desinteressantes” ou que “não fazem o tipo", segundo eles.

A busca online é, portanto, uma "prisão" de ideais que parecem nunca se concretizarem para além de poucas relações sexuais fortuitas. A fixação pela busca e nunca encontrar alguém não pode ser atribuída apenas à injustiças nos recortes de raça. Os meus colaboradores, como vimos, buscam brancos, com sinais de boa inserção social. As buscas que nunca terminam têm suas razões: a primeira delas é a de que as pessoas com os atributos que tanto são desejados são escassas e quase inacessíveis àqueles que não estejam no foco do desejo, ou melhor, as pessoas buscam se relacionar com pessoas que tenham minimamente similaridades sociais, como mostra o Ricardo que só se relaciona com “brancos” . Ao questioná-lo o motivo, ele dispara: "Não curto japas [...] rosto, olhos puxados, cabelos pretos. [...] não curto indígenas também por parecer japa. [...] não curto morenos, moreninhos também. Prefiro branquinho, lisinho, limpinho” ; a segunda razão, que atrapalha a primeira, tem a ver com o contexto da cidade, com poucos espaços de sociabilidade homoerótica, o que inviabiliza os relacionamentos que tenham similaridades sociais, já que usualmente compartilham dos mesmos espaços, como mostra Miguel - que não sai muito - ao não se relacionar com aqueles que estudam na mesma universidade que a sua. A terceira razão é a de que são restringidos a se relacionar por conta da falta de recursos financeiros, controle familiar, faculdade, trabalho e etc., que impedem, mesmo que subjetivamente, a concretização 
dos relacionamentos. Esta última razão fica clara quando vemos que Juliano mora com seus pais, mantendo uma presumida heterossexualidade. A frustração na busca e/ou escolha não é compreensível apenas pelo regime erótico local em torno dos homens brancos de elite, mas na própria incapacidade dos meus colaboradores de negociarem seus desejos com os constrangimentos sociais que vivem.

Percebi que existe algo, que parece estar naturalizado, que faz com que as pessoas racializadas geralmente esperem ser escolhidas, enquanto aqueles que são considerados “brancos" escolhem os seus parceiros em relações mediadas digitalmente. O que rege a busca nesse caso é a branquitude, que parece pairar sobre as relações como um ideal ou como um desejo.

Ao pensar sobre a branquitude, não poderíamos esquecer, no entanto, do Outro excluído, mas que é constituinte de branquitude. Hall (2008) mostra que “como todas as práticas de significação, ela está sujeita ao ‘jogo’ da différance” (p.106). Neste sentido o autor conclui o argumento dizendo que

uma vez que, como num processo, a identificação opera por meio da différance, ela envolve um trabalho discursivo, o fechamento e a marcação de fronteiras simbólicas, a produção de “efeitos de fronteiras” . Para consolidar o processo, ela requer aquilo que é deixado de fora - o exterior que a constitui (HALL, 2008, p.106).

Mas como pensar então a branquitude no contexto são-carlense? Este atributo naturalizado como um ideal a ser buscado ou mantido é constituído pelo Outro, que é excluído, mas que a constitui. Esse Outro, no caso desta pesquisa, é um espectro, um fantasma que assombra e constitui a branquitude como uma diferença.

Segundo Alvin (2000), o desconstrucionista Jacques Derrida define os fantasmas ou os espectros como “formas sem forma, que ainda assim, consegue tomar uma forma, podendo sempre se fazer presente de forma imprevisível. [...] É algo que não está nem presente, nem ausente [...] mas com o que devemos aprender a conviver” (p. 141).

Miskolci (2011) em “Frankenstein e o espectro do desejo” mostra que, segundo a socióloga norte-americana Avery F. Gordon,

a literatura que lida com espectros constitui fonte quase inexplorada, mas cuja análise permitiria uma melhor compreensão da relação entre história, subjetividade e vida social. Para explorar essa interseção seria necessário romper criticamente com uma epistemologia que considera o empírico como apenas o material, o evidente e o real desenvolvendo uma sociologia mais atenta ao afetivo, ao cultural e à experiência. (MISKOLCI, 2011, p.314). 
$O$ desejo pela branquitude e o fantasma das diferenças raciais: negociações das diferenças a partir do uso dos bate-papos na cidade de São Carlos

O fantasma é, segundo Miskolci (2011), uma figura social de violência e dano, os quais "assombram os vivos com a demanda de reconhecimento das injustiças que lhes foram infligidas” (p. 314) e o caráter múltiplo deste um constituído de muitos

lembra a ideia inicial de Freud sobre o inconsciente como um lugar onde todos os Outros vivem de nós mesmos. Outros sociais, portanto, todos os condenados, marginais, excluídos ou reprimidos, os que cruzaram a linha da transgressãosubversão da ordem, dos valores ou da moral vigentes (MISKOLCI, 2011, p.316).

O fantasma da negritude, e de suas articulações, assombra os meus colaboradores de pesquisa e os faz buscar reconhecimento de diversos modos. Como vimos, o Juliano e Guilherme tentam se "embranquecer" por meio da forma como se veste ou comporta, e Miguel e Ricardo buscam relacionamentos amorosos/sexuais com "brancos” bem alocados socialmente.

A minha intenção aqui não é a de contrapor “negros e japas” versus “brancos” , mas antes, mostrar que, no contexto são-carlense, onde todos parecem ser assombrados pelo fantasma da negritude e da homossexualidade, os sujeitos se agenciam se masculinizando, e buscando se “embranquecer” por meio do consumo, relacionamentos amorosos/sexuais, ou, até mesmo, tentando manter a sua posição por meio das rejeições, separando aqueles que são relacionáveis, daqueles que devem ser evitados a qualquer custo para não acabar se "enegrecendo" .

Não é possível afirmar que no contexto interiorano exista mais homofobia ou racismo do que nas grandes cidades. Antes, precisamos compreender que são consequências de dispositivos contextuais, ou seja, o fato de que os critérios de seleção sejam elevados no contexto são-carlense, diz respeito aos fantasmas que assombram radicalmente os corpos que buscam ser reconhecidos em ideais valorizados socialmente em um circuito pequeno, onde o risco de ser descoberto em sua sexualidade, ou de ser visto com alguém com diferenças constituídas negativamente, pode trazer consequências reais, afetando o grau de reconhecimento social que é almejado pelos meus colaboradores. 
NORUS - v3, n.3, jan - jun 2015.

\section{REFERÊNCIAS BIBLIOGRÁFICAS}

ALVIM, Luiza Beatriz Amorim Mello. Derrida: uma reflexão sobre a herança europeia e a desconstrução do eurocentrismo. In: NASCIMENTO, Evendo e GLENADEL, Paula (orgs.). Em torno de Jacques Derrida. Rio de Janeiro: 7Letras, 2000.

BELELI, Iara. Amores Online. In: PELÚCIO et al. Gênero, Sexualidade e Mídia: Olhares Plurais para o Cotidiano. Marília: Cultura Acadêmica, 2012.

FOUCAULT, Michel. História da Sexualidade I: A vontade de saber. São Paulo: Graal, 1993.

HALL, Stuart. Quem precisa de identidade?. In. Tomaz Tadeu da Silva (org.). Identidade e diferença: a perspectiva dos estudos culturais. Petrópolis, RJ: Vozes, 2008.

ILLOUZ, Eva. O amor nos tempos do capitalismo. Rio de Janeiro: Zahar, 2011.

MISKOLCI, Richard. A gramática do armário: notas sobre segredos e mentiras em relações homoeróticas masculinas mediadas digitalmente. LASA 2012 Congress Paper Archive. v. 1. p. 1-25, Pittsburgh: LASA, 2012.

. Comentário. Cadernos Pagu no.28, p. 55-63, 2007.

. Frankenstein e o espectro do desejo. Cadernos Pagu n.37, p. 299-322, 2011.

O armário ampliado: notas sobre sociabilidade homoerótica na era da internet". Gênero, UFF, v. 9, n. 2, p. 171-190, 2009.

. O desejo da nação: masculinidade e branquitude no Brasil de fins do XIX. São Paulo: Anablume, 2012b.

. Negociando visibilidades: segredo e desejo em relações homoeróticas masculinas $\overline{\text { criadas }}$ por mídias digitais. Mimeo. 2014.

. Networks of desire:The Specter of aids and the Use of Digital Media in the Quest for Secret Same-Sex Relations in São Paulo. Vibrant - Virtual Brazilian Anthropology, Brasília, v. 10, n. 1. 2013. Disponível em: http://www.vibrant.org.br/issues/v10n1/richard-miskolcinetworks-of-desire. Acesso em: 10/12/2014.

SEDGWICK, Eve Kosofsky. Epistemologia do Armário. Cadernos Pagu. n.28, p. 19-54, 2007.

SIBILIA, Paula. O show do eu: A intimidade como espetáculo. Rio de Janeiro: Nova Fronteira, 2008.

SILVÉRIO, Valter Roberto. Multiculturalismo e metamorfose na racialização: notas preliminares sobre a experiência contemporânea brasileira. In: Maria da Gloria Bonelli \& Martha Diaz Villegas de Landa [Orgs.]. Sociologia e mudança social no Brasil e na Argentina. São Carlos: Compacta Gráfica e Editora, 2013. 
O desejo pela branquitude e o fantasma das diferenças raciais: negociações das diferenças a partir do uso dos bate-papos na cidade de São Carlos

SIMÕES, Júlio Assis, FRANÇA, Isadora Lins e MACEDO. Jeitos de Corpo: cor/raça, gênero, sexualidade e sociabilidade juvenil no centro de São Paulo. Cadernos Pagu. n. 35, p.37-78, 2010 .

ZAGO, Luiz Felipe. Masculinidades disponível.com: como se dizer homem gay na internet. Porto Alegre, [Dissertação de Mestrado em Educação], UFRGS, 2009. 